\title{
Relationship between the Quality of Administrative System and Health Care Provided to the Patients among Hospital Managers
}

\author{
${ }^{1}$ Amany A. El Nahas, ${ }^{2}$ Manal M. Bakr and ${ }^{3}$ Nabila M. Shrief \\ ${ }^{I}$ Nurse specialist, Technical Nursing Institute, Kafr El-Sheikh, ${ }^{2}$ Assistant \\ professor of Nursing Administration, ${ }^{3}$ Lecturer of Nursing Administration, \\ Faculty of Nursing, Menoufia University
}

\begin{abstract}
Administration in hospital is the art and science of guidance, leadership, and control of the efforts of a group of individuals towards some common goal. A common goal is "Quality Patient Care". And the hospital administrator has a great responsibility to understand and appreciate the aspects of patient care. The purpose of the study was to examine the relationship between the quality of administrative system and health care provided to patients among hospital managers. Design: A descriptive correlational research design was utilized in the current study. Setting: This study was conducted at inpatient and critical care units at Menoufia University Hospitals. Methods: A simple random sample for each category of study participants was done. They were 57 Nurses' managers, 55 physicians' managers, 33 administrative managers, and 75 patients. Two instruments were used for data gathering. The first instrument was managers' observational checklist. The second instrument was patients' structured interview questionnaire. Results: The main findings of this study revealed that the administrative system total quality in Menoufia University Hospital among managers was high (70.3\%). Majority of patients denoted that the quality of health services were moderate quality. Conclusion: More than two thirds of patients' perceived that the quality of services was moderate. There was high significant difference between patients' perception and all hospital managers and the total quality score of administrative system. It was recommended that hospital administrators should take action to provide adequate staff and resources at any time to maintain and continuously improve the quality of health care and quality of administrative system. Managers should make ongoing monitoring of patient satisfaction specific to nursing and medical services regularly. Further researches studies are required to pay more attention toward comparing between in-patient departments regard quality of structure of administrative system.
\end{abstract}

Keywords: Administrative System, quality, Health Care, Patients.

\section{Introduction}

Administration is the organization and direction of human and material resources. It is a determinative or thinking function, which is concerned with determination of major objectives and policies. The main functions of administration are planning and controlling which require conceptual and human skills. While, management is the coordination of all resources through the process of planning, organizing, directing and controlling to attain stated objectives. Management is an executive or doing function, which is concerned with the implementation of policies. The main functions of management are directing and organizing that require technical and human skills (Kelly, 2012).

Quality in healthcare is a production of cooperation between the patient and the health care provider in a supportive environment. Personal factors of the provider and the patient, and factors pertaining to the healthcare organization, healthcare system, and the broader environment affect healthcare service quality. Health care quality can be improved by supportive visionary management, proper planning, education and 


\section{Relationship between the Quality of Administrative System and Health Care Provided to the Patients among Hospital Managers}

training, availability of resources, effective management of resources, employees and processes, and collaboration and cooperation among health care providers (Mosadeghard, 2014).

To be successful as managers, manager, you should have better planning and decision- making skills, good organizing and directing skills (Williams, 2013).

Effective patient outcomes require quality administrative system, which include planning, organizing, directing, and controlling (American Physical Therapy Association, 2017).

Planning involves determining organizational goals and means for achieving them. Planning needs knowledge, experience, special skills and techniques. It must be futuristic, decision-making process, dynamic and flexible (Williams, 2013).

Planning is a process of thinking before doing, it produce a scheme for future actions, avoids risks and uncertainty, lead to success and facilitate controlling function. There are various different approaches to health service planning which can range from problem solving to long term and short term plans to achieve pre-determined objectives. The outcome of planning is conditioned by behaviors of individuals at all levels in the process that facilitate effective use of resources for better health care for patients (Marquis, and Huston, 2010).

Organizing is the formal system of working relationships. Once the objectives have been established through planning, management is concerned with developing an organization capable of carrying them out. Manager is responsible for identifying particular tasks and assigning them to individuals or teams who have the training and expertise to implement them and coordinating activities to meet the units' objectives. Organizing provides a variety of innovative models of care, and provide cost effective care for patients through different strategies and methods (Bathavanthappa, 2009).

Directing includes the activities of giving orders, making supervision, leading, motivating, and communicating. It involves giving instructions, counseling, and motivating the staff in an organization to achieve organizational goals. Directing is a continuous process initiated at top level and flows to the bottom through organization hierarchy (Ahmed, 2014).

Directing is considered a mean for motivation to improve employees performance and encourage them to give the best of their abilities, provide stability and balance for growth of the organization. Effective communication helps in coping with changes and the role of manager is to communicate the nature and content of change very clearly to hospital employees.

Directing helps in clarifying the role of each employee toward his work and proper utilization of resources. Through direction, the role of employees become clear as manager makes use of his supervisory, guidance, instructions, motivation skill to inspire subordinates that create a good culture that improve the care provided by hospital staff to patients and achieve higher quality patient care (Marquis, and Huston, 2010).

Controlling, is monitoring the progress of employees toward goal achievement and taking corrective action when progress is not being made. The basic control process involves setting standards to achieve 


\section{Relationship between the Quality of Administrative System and Health Care Provided to the Patients among Hospital Managers}

goals, comparing the actual performance to standards and then making changes to return performance to those standards (Williams, 2013).

Through good Controlling, the hospital made performance appraisal process more formal and use it as a tool to identify employees' performance, their training needs, rewards, bonuses and career development to provide high quality patient care and improve patient outcomes (Marquis, and Huston, 2010).

Health care system have three simple components: structure, process, and outcome. Structure of the administrative system is the arrangement of parts within the larger whole and is concerned with the setting, process of the administrative system is concerned with what happens or how the care is delivered, and the outcome of the administrative system is demonstrated by improved patients' outcomes. Good structure lead to good process and good process result in good outcome (Huber, 2018).

It is necessary for the hospitals to provide the best medical nursing, administrative and supportive facilities for patients and keep track of it day-to-day throughout the presence of high quality administrative system to achieve success and increase productivity for the hospital (Hospital Management System Project, 2014).

\section{Significance of the study}

Strong management system underline structure, process and outcomes of hospital is necessary to smooth running of health care process. it is essential that efficient administrative systems are in place, working and used by all health care providers. Administrative system is essential for achieving high quality care, which is the right for all patients and the responsibility of all health care providers.

Donabedian quality of care model (1980) used as a framework guided to the study. Donabediane describes quality care as a model, comprising different dimensions: structure, process and outcome. This model has been widely used, especially for monitoring and improving the quality care. Structure denotes the attributes of material resources such as facilities and equipment. Process denotes what is actually done in giving and receiving care (practitioner activities in making diagnosis, recommending treatment or interacting with patients). Outcome measures attempt to describe the effects of care on the health status of patients and populations (Salah, 2016).

\section{Purpose of the study}

The study aimed to examine the relationship between the quality of administrative system and health care provided to the patients among hospital managers.

\section{Research Question}

1. What are the quality levels of administrative system at Menoufia university hospital structure, process and outcome among managers?

2. What are the levels of health care provided to the patients?

3 . Is there a relationship between the quality of administrative system and health care provided to the patients as experienced by hospital managers?

\section{Methods}

Research design: A descriptive correlational research design was used in the current study.

Research setting: This study was conducted at inpatient and critical 


\section{Relationship between the Quality of Administrative System and Health Care Provided to the Patients among Hospital Managers}

care units at Menoufia University Hospitals.

Sampling: Sample size has been calculated utilizing $G$ power analysis and using the following formula: $\mathrm{n}=$ $\left[\mathrm{DEFF}^{*} \mathrm{~Np}(1-\mathrm{p})\right] /\left[\left(\mathrm{d}^{2} / \mathrm{Z}^{2}{ }_{1-} \propto *(\mathrm{~N}-\right.\right.$ $\left.1)+p^{*}(1-p)\right]$ at power $80 \%$ and CI $95 \%$. The total sample size of the study was 220 participants (Kevin \& Sullivan, 2018).

The sample included four groups:

Group 1: all nurse managers (57) which (Nurse Director (1), Nursing Supervisors of hospitals (12), and Heads Nurses (44)).

Group 2: all physician managers (55) which distributed as: hospital directors (5), physician administrative deputies (6), and unit medical managers (44).

Group 3: all administrative managers (33) which included: general directors (3), administrative deputies (7) and heads of administrative departments (23) were selected from Menoufia university hospitals.

Group 4: A convenient sample of 75 patients was selected to constitute the present study sample from Menoufia university hospitals.

Instruments: Two instruments were used to collect data:

Instrument one: It involved Managers' observational checklist. It was developed by the researcher based on a review of current related literature (Adams \& Arber, 1995., Aly, 2011., Ibrahim, 2016). For observation of nurse managers, physician managers and administrative managers (to evaluate their tasks regarding the quality of administrative system at Menoufia University hospital). The instrument is divided into three parts. They are quality administrative system structure, quality of process of administrative system and quality of outcome of administrative system. The administrative system included 89 items, structure contained sixteen items, process contained 63 items Ten for planning, nine for organizing, eight for directing, ten for coordinating, ten for controlling, seven for leading and nine for working relationship and outcome contained ten items.

\section{Scoring system of participants'} observational checklist:

There were two responses for each item $(0=$ Not done and $1=$ Done).

\begin{tabular}{|l|l|}
\hline Not Done & 0 \\
\hline Done & 1 \\
\hline
\end{tabular}

Total scoring system:

\begin{tabular}{|l|c|}
\hline Low & $0-29.6$ \\
\hline Moderate & $29.7-59.3$ \\
\hline High & $59.4-89$ \\
\hline
\end{tabular}

Instrument two: Patients structured interview. It was developed by the researcher to investigate the patients' perception toward quality of health care provided by hospital staff in Menoufia University hospital. The researcher developed it based on review of current related literature (Mohamed, 1998., Williams, 2015). It included two parts as follows:

- Part A: Demographic data such as: unit, sex, age, educational level, job, and marital status.

- Part B: It included questions to assess the perception of patients towards the quality of health care provided by hospital staff in Menoufia University hospital. It included 52 questions distributed under five categories which are: hospital characteristics (4 items), physicians services (13 items), nurses services (12 items), supportive services (16 items), and 


\section{Relationship between the Quality of Administrative System and Health Care Provided to the Patients among Hospital Managers}

administrative employees services (7 items).

Scoring system for the quality of health care:

Each instrument was scored as follows:

\begin{tabular}{|l|l|}
\hline Strongly Disagree & 1 \\
\hline Disagree & 2 \\
\hline No definite opinion & 3 \\
\hline Agree & 4 \\
\hline Strongly Agree & 5 \\
\hline
\end{tabular}

Total scoring system:

\begin{tabular}{|l|c|}
\hline Low & $52-121.3$ \\
\hline Moderate & $121.4-190.6$ \\
\hline High & $190.7-260$ \\
\hline
\end{tabular}

\section{Data collection procedure:}

\section{Ethical considerations:}

1- A formal letter was submitted from the Dean of the Faculty of Nursing, Menoufia University to the director of Menoufia University hospital explaining the purpose and methods of data collection.

2- Each participant was individually interviewed.

3- Each interview lasted for 20-25 minutes. The researcher started by asking questions about hospital characteristics then, each participant was asked about the services provided to them by nurses, physicians, administrative employees, and support services.

\section{Validity:}

The data collection instruments were developed by researcher after extensive review of past and current, local and international related literature. The instruments were revised for content validity by eleven juries (five experts from Tanta University, one expert from Cairo University, one expert from EinShams University, one expert from Helwan University, and three experts from Menoufia University) who were experts in in nursing administration.

\section{Reliability:}

The instruments were tested for reliability by Cronbach's coefficiency Alpha (0.85) for the MUH managers questionnaire, and 0.78 for the patient questionnaire. Necessary modifications including clarifications, omissions, of some questions and rephrasing of other were done.

\section{Pilot study:}

- A pilot study was carried out on $(10 \%)$ of the total sample (ten staff nurses, ten staff physicians, ten of administrative staff and ten patients) and data was analyzed and compared.

- The collection of data was started at 10 June 2017 and ended at 10 October 2017, lasted for four months.

\section{Statistical Analysis:}

Data was entered and analyzed by using SPSS version 22. Quantitative data were presented by mean $(\mathrm{X})$ and standard deviation (SD). It was analyzed using student ttest for comparison between two means, and ANOVA (F) test for comparison between more than two means. Qualitative data were presented in the form of frequency distribution tables, number and percentage. It was analyzed by chi-square $\left(\chi^{2}\right)$ test. However, if an expected value of any cell in the table was less than 5, Fisher Exact test was used( if the table was 4 cells), or Likelihood Ratio (LR) test (if the table was more than 4 cells). A statistical significant difference was considered if $\mathrm{P}<.05$. A highly statistical significant difference was considered if $\mathrm{P}<.01$ 


\section{Relationship between the Quality of Administrative System and Health Care Provided to the Patients among Hospital Managers}

Results:

Figure 1. Demonstrated the distribution of studied managers according to their jobs. As indicated in the figure, the nurse managers constituted 39.3\%, followed by physician managers $(37.9 \%)$ and the least percentage was the administrative managers $(22.8 \%)$.

Figure 2. Showed the distribution of patients participants according to their Socio-demographic characteristics. As figure shows that forty percent of patients were from ICU, approximately three quarters of them were females, $58.7 \%$ of them aged less than 30 years, $70.6 \%$ of them had high school, and $32 \%$ of them were housewives. As regards marital status, $64 \%$ of them were married and $36 \%$ were unmarried.

Table 1. highlighted the administrative system total quality in MUH among managers' participants. As noticed in this table, the total mean score was $66.5 \pm 8.8$. Administrative managers showed the highest total mean score was $74.8 \pm 6$, followed by physician managers $(70.5 \pm 6.2)$, and the lowest mean score was among nurse managers $(57.9 \pm 3.2)$. The

difference was highly significant statistically $\quad(\mathrm{P}=0.000) . \quad 70.3 \%$ of studied managers showed high total quality in MUH. More than two thirds $(66.7 \%)$ of nurse managers showed moderate total quality, compared to $3 \%$ among administrative managers. Only $33.3 \%$ of nurse managers had high level of quality in MUH, compared to $97 \%$ among administrative managers, and $92.7 \%$ among physician managers. This difference was highly statistical significant $(\mathrm{P}=0.000)$.
Table 2. demonstrated the perception of patients towards health care provided by MUH. As inferred in this table, majority of patients denoted moderate quality regarding the following domains: hospital characters $(41.3 \%)$, services provided to patients by administrative employee (56\%), services provided to patients by physicians (57.3\%), services provided to patients by nurses $(60 \%)$, and services provided to patients by supportive services $(58.7 \%)$. There were statistical significant differences between male and female patients regarding their opinions about quality of services provided by administrative employee $(\mathrm{P}=0.003)$, services provided by nurses $(\mathrm{P}=0.03)$, and total score of health care provided by MUH $(\mathrm{P}=0.04)$.

Table 3. Showed the relationship between the quality of administrative system among hospital managers and health care provided to the patients at Menoufia University hospital. As presented in this table, no one of managers showed low total score in quality, $14.7 \%$ of patients perceived that the quality of services provided by MUH was low, more than two thirds of patients perceived that the quality of services provided by $\mathrm{MUH}$ was moderate $(66.7 \%)$, and less than one fifth had high perception $(18.6 \%)$. There were highly statistical significant differences between patients perception and each of nursing managers, physicians managers, administrative managers, and total quality score administrative system $(\mathrm{P}=0.004, \mathrm{P}=0.000, \mathrm{P}=0.000$, $\mathrm{P}=0.000$ respectively)

Fig 1: Distribution of studied managers according to their jobs $(\mathrm{N}=145)$ 
Relationship between the Quality of Administrative System and Health Care

Provided to the Patients among Hospital Managers

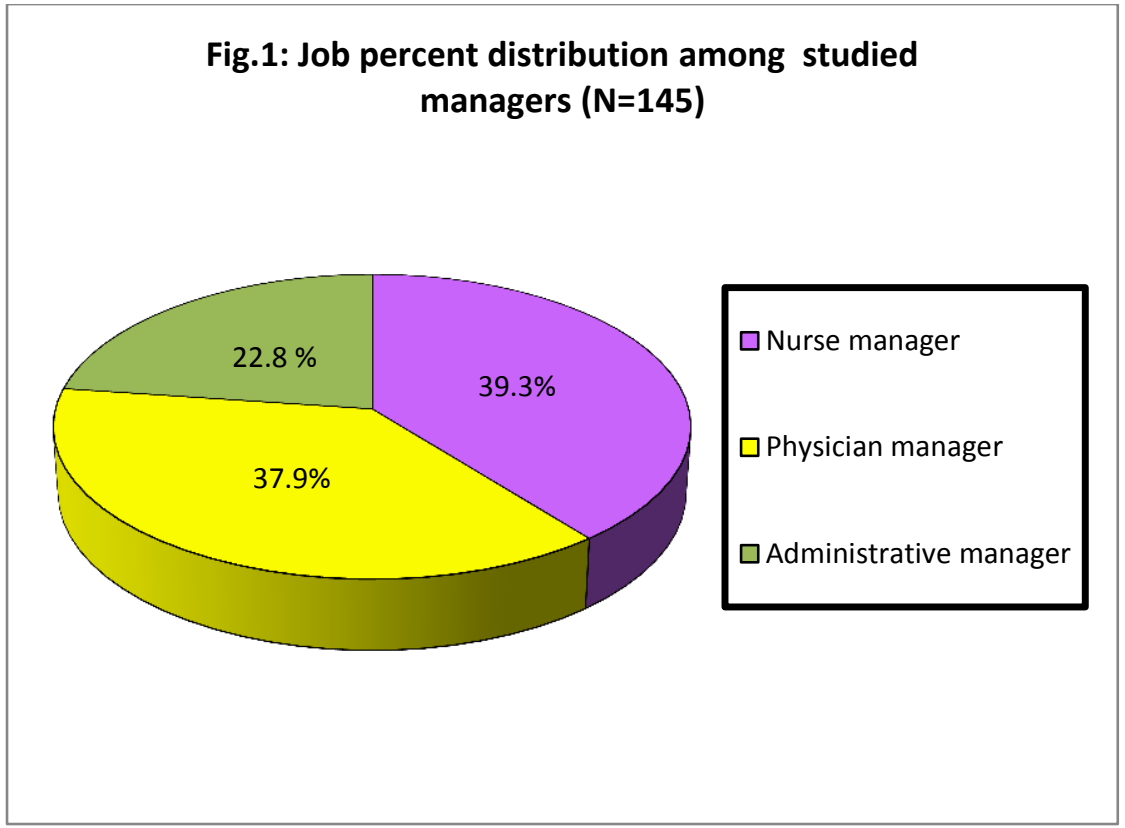

Fig 2: Distribution of patients participants according to their Socio -demographic characteristics $(\mathrm{N}=75)$

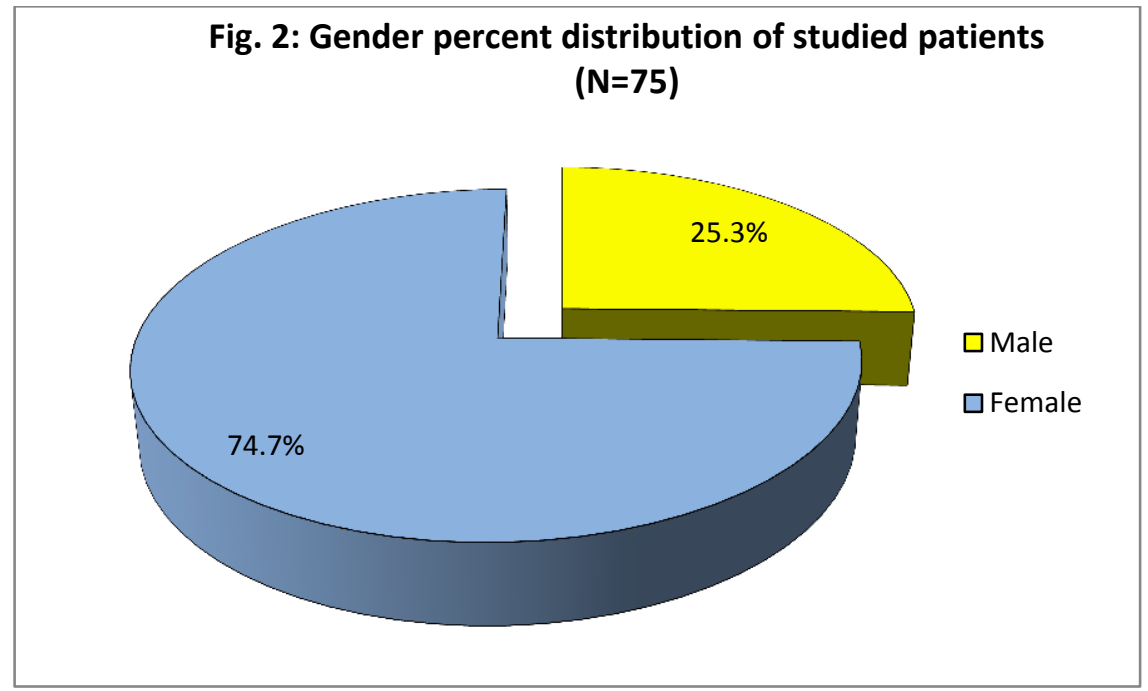

Table 1. Total quality of the administrative system in MUH among managers' participants (structure, process and outcome)

\begin{tabular}{|c|c|c|c|c|c|c|c|c|c|}
\hline \multirow{3}{*}{$\begin{array}{c}\text { Quality of administrative } \\
\text { system }\end{array}$} & \multicolumn{6}{|c|}{ Managers participants } & \multirow{2}{*}{\multicolumn{2}{|c|}{ Total }} & \multirow{3}{*}{ P value } \\
\hline & \multicolumn{2}{|c|}{$\begin{array}{c}\text { Nurse } \\
\text { managers }\end{array}$} & \multicolumn{2}{|c|}{$\begin{array}{l}\text { Physician } \\
\text { managers }\end{array}$} & \multicolumn{2}{|c|}{$\begin{array}{c}\text { Administrative } \\
\text { managers }\end{array}$} & & & \\
\hline & no. & $\%$ & no. & $\%$ & no. & $\%$ & no. & $\%$ & \\
\hline Moderate $(29.7-59.3)$ & 38 & 66.7 & 4 & 7.3 & 1 & 3 & 43 & 29.7 & \multirow{3}{*}{$\begin{array}{c}\mathrm{LR}=61.8, \\
\mathrm{P}=0.000 \mathrm{HS}\end{array}$} \\
\hline High (59.4- 89) & 19 & 33.3 & 51 & 92.7 & 32 & 97 & 102 & 70.3 & \\
\hline Total & 57 & 100 & 55 & 100 & 33 & 100 & 145 & 100 & \\
\hline Mean \pm SD & \multicolumn{2}{|c|}{$57.9 \pm 3.2$} & \multicolumn{2}{|c|}{$70.5 \pm 6.2$} & \multicolumn{2}{|c|}{$74.8 \pm 6$} & \multicolumn{2}{|c|}{$66.5 \pm 8.8$} & \multirow{2}{*}{$\begin{array}{c}\mathrm{F}=137.7, \\
\mathrm{P}=0.000 \mathrm{HS}\end{array}$} \\
\hline Range & \multicolumn{2}{|c|}{$51-64$} & \multicolumn{2}{|c|}{$50-81$} & \multicolumn{2}{|c|}{$59-84$} & \multicolumn{2}{|c|}{$50-84$} & \\
\hline
\end{tabular}

Table 2. Assessing the perception of patients towards health care provided by hospital staff $(\mathrm{N}=75)$ 


\section{Relationship between the Quality of Administrative System and Health Care Provided to the Patients among Hospital Managers}

\begin{tabular}{|c|c|c|c|c|c|c|c|c|}
\hline \multirow{3}{*}{\multicolumn{2}{|c|}{$\begin{array}{l}\text { Perception of patients towards health care } \\
\text { provided by hospital staff }\end{array}$}} & \multicolumn{4}{|c|}{ Patients participants } & \multirow{2}{*}{\multicolumn{2}{|c|}{ Total }} & \multirow{3}{*}{$P$ value } \\
\hline & & \multicolumn{2}{|c|}{ Male } & \multicolumn{2}{|c|}{ Female } & & & \\
\hline & & no. & $\%$ & no. & $\%$ & no. & $\%$ & \\
\hline \multirow{3}{*}{ Hospital characters } & Low (4-9.3) & 5 & 26.4 & 20 & 35.7 & 25 & 33.4 & \\
\hline & Moderate(9.4 - 14.6) & 7 & 36.8 & 24 & 42.9 & 31 & 41.3 & \multirow{2}{*}{$\begin{array}{c}\mathrm{X}^{2}=1.8, \mathrm{P}=0.4 \\
\mathrm{NS}\end{array}$} \\
\hline & High (14.7 - 20) & 7 & 36.8 & 12 & 21.4 & 19 & 25.3 & \\
\hline \multirow{3}{*}{$\begin{array}{l}\text { Physicians health } \\
\text { services }\end{array}$} & Low (13 -30.3) & 4 & 21.1 & 13 & 23.2 & 17 & 22.7 & \multirow{3}{*}{$\begin{array}{l}\mathrm{X}^{2}=0.63, \mathrm{P}=0.7 \\
\mathrm{NS}\end{array}$} \\
\hline & Moderate( 30.4 -47.6) & 10 & 52.6 & 33 & 58.9 & 43 & 57.3 & \\
\hline & $\operatorname{High}(47.7-65$ & 5 & 26.3 & 10 & 17.9 & 15 & 20 & \\
\hline \multirow{3}{*}{$\begin{array}{l}\text { Nurses health } \\
\text { services }\end{array}$} & $\operatorname{Low}(12-28)$ & 2 & 10.5 & 6 & 10.7 & 8 & 10.7 & \multirow{3}{*}{$\begin{array}{l}\mathrm{X}^{2}=7.9, \mathrm{P}=0.03 \\
\text { Sig. }\end{array}$} \\
\hline & Moderate(28.1-44.1) & 7 & 36.8 & 38 & 67.9 & 45 & 60 & \\
\hline & $\operatorname{High}(44.2-60)$ & 10 & 52.7 & 12 & 21.4 & 22 & 29.3 & \\
\hline \multirow{3}{*}{$\begin{array}{l}\text { Supportive health } \\
\text { services }\end{array}$} & $\operatorname{Low}(16-37.3)$ & 6 & 31.5 & 13 & 23.2 & 19 & 25.3 & \multirow{3}{*}{$\begin{array}{c}\mathrm{X}^{2}=1.3, \mathrm{P}=0.50 \\
\text { NS }\end{array}$} \\
\hline & Moderate(37.4-58.6) & 9 & 47.4 & 35 & 62.5 & 44 & 8.7 & \\
\hline & High(58.7- 80) & 4 & 21.1 & 8 & 14.3 & 12 & 16 & \\
\hline \multirow{3}{*}{$\begin{array}{c}\text { Administrative } \\
\text { employee health } \\
\text { services }\end{array}$} & $\operatorname{Low}(7-16.3)$ & 3 & 15.8 & 12 & 21.4 & 15 & 20 & \multirow{3}{*}{$\begin{array}{c}X^{2}=11.6 \\
P=0.003 \text { Sig. }\end{array}$} \\
\hline & Moderate (16.4- 25.6) & 6 & 31.6 & 36 & 64.3 & 42 & 56 & \\
\hline & High (25.7- 35) & 10 & 52.6 & 8 & 14.3 & 18 & 24 & \\
\hline \multirow{3}{*}{$\begin{array}{c}\text { Total Score } \\
\text { Range }=52-260\end{array}$} & Low $(52-121.3)$ & 2 & 10.5 & 9 & 16.1 & 11 & 14.7 & \multirow{3}{*}{$\begin{array}{l}\mathrm{X}^{2}=7.5, \mathrm{P}=0.04 \\
\text { Sig. }\end{array}$} \\
\hline & Moderate (121.4-190.6) & 10 & 52.7 & 40 & 71.4 & 50 & 66.7 & \\
\hline & High(190.7- 260) & 7 & 36.8 & 7 & 12.5 & 14 & 18.6 & \\
\hline & Total & 19 & 100 & 56 & 100 & 75 & 100 & \\
\hline
\end{tabular}

Table 3. The associative relation between the quality of administrative system and health care provided to the patients at Menoufia University hospital among managers

\begin{tabular}{|c|c|c|c|c|c|c|c|c|c|c|}
\hline \multirow{3}{*}{$\begin{array}{c}\text { Quality of } \\
\text { administrative } \\
\text { system among } \\
\text { managers }\end{array}$} & \multicolumn{6}{|c|}{ Managers' participants } & \multirow{2}{*}{\multicolumn{2}{|c|}{ Total }} & \multirow{2}{*}{\multicolumn{2}{|c|}{$\begin{array}{c}\text { Patients } \\
\text { perception } \\
\text { about health } \\
\text { care in MUH } \\
\end{array}$}} \\
\hline & \multicolumn{2}{|c|}{$\begin{array}{l}\text { Nursing } \\
\text { Mangers }\end{array}$} & \multicolumn{2}{|c|}{$\begin{array}{c}\text { Physician } \\
\text { mangers }\end{array}$} & \multicolumn{2}{|c|}{$\begin{array}{l}\text { Administrative } \\
\text { mangers }\end{array}$} & & & & \\
\hline & No. & $\%$ & No. & $\%$ & No. & $\%$ & No. & $\%$ & No. & $\%$ \\
\hline Low & 0 & 0 & 0 & 0 & 0 & 0 & 0 & 0 & 11 & 14.7 \\
\hline Moderate & 38 & 66.7 & 4 & 7.3 & 1 & 3 & 43 & 29.7 & 50 & 66.7 \\
\hline High & 19 & 33.3 & 51 & 92.7 & 32 & 97 & 102 & 70.3 & 14 & 18.6 \\
\hline Total & 57 & 100 & 55 & 100 & 33 & 100 & 145 & 100 & \multirow[t]{2}{*}{75} & 100 \\
\hline$* \chi^{2}$ & \multicolumn{2}{|c|}{$\chi^{2}=8.1$} & \multicolumn{2}{|c|}{$\chi^{2}=58.0$} & \multicolumn{2}{|c|}{$\chi^{2}=44.3$} & \multicolumn{2}{|c|}{$t=60.1$} & & \\
\hline *P value & \multicolumn{2}{|c|}{$\mathrm{P}=0.004 * *$} & \multicolumn{2}{|c|}{$\mathrm{P}=0.000 * *$} & \multicolumn{2}{|c|}{$\mathrm{P}=0.000^{* *}$} & \multicolumn{2}{|c|}{$\mathrm{P}=0.000 * *$} & & \\
\hline Mean \pm SD & \multicolumn{2}{|c|}{$57.9 \pm 3.2$} & \multicolumn{2}{|c|}{$70.5 \pm 6.2$} & \multicolumn{2}{|c|}{$74.8 \pm 6$} & \multicolumn{2}{|c|}{$\mathrm{F}=42.5, \mathrm{P}=0.000 * *$} & \multicolumn{2}{|c|}{$157.8 \pm 35.4$} \\
\hline
\end{tabular}

$\mathrm{F}$ test $=$ Comparison between each of nursing, physician, administrative managers, and total managers 'mean \pm SD of total score of quality of administrative system with mean \pm SD of total score of patients perception about Menoufia University Hospital services. ns = $\mathrm{P}>.05 \quad *=\mathrm{P} \leq .05 \quad * *=\mathrm{P} \leq .01$

\section{Discussion:}

All the doctors' managers, all nurse managers, and all administrative managers should have a good understanding of hospital organization and management system to provide better care for their patients. Moreover, they should also have enough knowledge for management of human, material and financial resources in a cost effective way with optimum time approach. All hospital managers have a legal and moral obligation to ensure a high quality of patient care because they are in a prime position to mandate policy, systems, procedures and organizational climates (Siddqui, 2018). The vision on nursing is to provide high quality of nursing care through high 


\section{Relationship between the Quality of Administrative System and Health Care Provided to the Patients among Hospital Managers}

quality of administrative system hospital as it reflects on nursing management services. Nurses as providers, become involved in the challenges related to quality of hospital administrative system and how to define, measure, and improve it (Huber, 2018).

Regarding quality of administrative system, the current study revealed that the total mean score of quality of administrative system (structure, process, and outcome) was high. Administrative managers showed the highest total mean score, followed by Physician managers, and then nurse managers. This was consistent with Mohamed (2002) who "studied the relationship between job satisfaction and absenteeism among nurses". They found that there was high level of quality in the work system, administration and work procedures. These could be attributed to good working conditions, higher managers' experiences and knowledge, participative management style, and good relationships among colleagues. Nurse manager is an important part of the administration cycle but they had the lowest mean score because they do not have enough time for carrying out management functions such as organizing, controlling and directing. They provide direct and indirect care, and practice non-nursing activities and do not have enough knowledge or training about job description of managers. This was contradicted with Gad (2002) which was related to quality of care as perceived by nurses, physicians and health care consumers. They found that structure approach had higher mean score than outcome approach as evaluated by nurses and doctors.

Regarding the structure quality of hospital administrative system, the current study revealed that the total mean score of the hospital structure was high. Physician managers showed the highest mean score, followed by administrative managers, then nurse managers.

This was consistent with Ahmed (2014) who studied "the effect of nursing management process applied by head nurses on quality of patient care in the main Mansoura University Hospital", and Cortelyou-Ward (2009) who studied "work environment and the effect on occupational commitment and intent to leave."Also, it was consistent with Elbialy and Abd Elaal (2013). Who studied "essentials of magnetism as perceived by staff nurses at Alexandria German hospital". They found that the majority of participants agreed on the presence of facilities for patients, relatives, and nurses. These could be attributed to availability of supplies, and equipment, good workplace maintenance for tools and equipment.

On the other hand, these findings were contradicted with Gharib (2013)who studied "job satisfaction of nursing staff versus patient satisfaction with the quality of nursing services at Cairo university hospitals". They found that there were unavailability of enough supplies in the hospital unit and nursing staff expressed low level of satisfaction.

Regarding process components of hospital administrative system, the current study revealed that the total mean score was a high. Administrative managers showed the highest mean score, followed by physician managers, and the lowest mean score was among nursing managers. This was contradicted with Ahmed (2014). Who studied "the effect of nursing management process applied by head nurses on the quality of patient care in the main Mansoura university hospital". She found that nurse managers recorded acceptable level regarding staffing, controlling, while they recorded unacceptable level of planning, organizing and directing process application. These could be attributed to in the current study there were good 


\section{Relationship between the Quality of Administrative System and Health Care Provided to the Patients among Hospital Managers}

working conditions, higher managers' experiences and knowledge, participative management style, and good relationships among colleagues.

Nurse manager is an important part of the administration cycle but they had the lowest mean score because they do not have enough time for carrying out management functions as organizing, controlling and directing. They provide direct and indirect care, and practice non-nursing activities and do not have enough knowledge or training about job description of managers. Also, this result may come back to small sample size of administrative managers comparing to big sample size of nurse managers.

Regarding the outcome quality of hospital administrative system, the current study revealed that the total mean score of the administrative system quality of outcome was high quality outcome. Administrative managers showed the highest mean score followed by physician managers. Nurse managers scored moderate quality outcomes. This was contradicted with Gad (2002). Who studied "quality of care as perceived by nurses, physicians and health care consumers". They found that there was low quality of hospital outcomes because the administration does not take care of measuring quality improvement and does not take care of patients after discharge. The researcher viewed that, the lack of patients' outcomes is related to many factors such as shortage of nursing staff, poor time management skills for nurses and nurse managers, and the hospital administration were not performing patient education.

Also, nurse managers have more contact with patients, their families, and other health care team and are not able to organize their time which negatively impact the quality of outcomes.

Regarding the quality of health care services provided to patients, the current study revealed that majority of patients showed moderate quality regarding the services provided to patients by nurses, service provided by supportive services, services provided by physicians then services provided by administrative employees.

This was consistent with Adam \& Elsawi (2011) who studied "patient satisfaction with health care". They found that the level of patient satisfaction with hospital services was moderate level in the study setting. On the other hand, this was contradicted with Gharib (2013) who studied "the job satisfaction of nursing staff versus patient satisfaction with the quality of nursing services at Cairo university hospitals".

She found that patients had low satisfaction regarding the health services provided to them. These could be attributed to patients rooms are not comfortable, physical facilities are insufficient, cleaning services in hospital is moderate, shortage of staff, and work overload. Nurses showed the highest percentage than other groups regarding the services provided to patients because they pay remarkable care and concerns about patients' health, respond quickly to their calls, spend more time with patients, and give patients adequate and effective explanation about their condition and treatment.

Regarding the relationship between the quality of administrative system among managers and health care provided to the patients at Menoufia University hospital, the current study revealed that no one of managers showed low total quality scores, low percent of patients showed low total quality while, more than two thirds of patients' perceived that the quality of services provided by hospital staff was moderate.

This was consistent with Parand, et al. (2014) who studied "the role of hospital managers in quality and patient safety". They found that the time spent activities 


\section{Relationship between the Quality of Administrative System and Health Care Provided to the Patients among Hospital Managers}

and engagement of hospital managers and boards were positively influence quality and safety performance. In the same context, this was similar to Hussein (2014). Who studied "the relationship between nurses and physicians' perceptions of organizational health and quality of patient care". He found that there was a significant positive correlation between participants' perception of determinants of the organizational hospital health and the predictors of quality patient care.

This result may be managerial personnel are not oriented with the day-to-day health care activities so they disagreed with patients opinions that the quality of services was moderate and they recorded that quality of services was high.

\section{Conclusion}

Although no one of managers showed low total score quality, more than two thirds of patients' perceived that the quality of services provided by Menoufia University Hospital was moderate. There were differences between patients' perception and each of nursing managers, physician managers and administrative managers

\section{Recommendations:}

Hospital administrators, accrediting agencies and regulators should take action to provide staff and resources at any time to maintain and continuously improve the quality of health care and quality of administrative system. Managers should make ongoing monitoring of patient satisfaction specific to nursing and medical services regularly. Staff development programs are needed for managers to integrate staff in decision-making and to deal effectively with new ideas to promote satisfactory organizational climate and satisfaction of staff. For further research, studies are required to pay more attention toward comparing between in-patient departments regard quality of structure of administrative system.

\section{References:}

Adams, A., and Arber S. (1995). Development and validation of scales to measure organization features of acute hospital wards. International of Nursing studies; 32(6): 612-27.

Adam, S.M. and Elsawi, K.A. (2011). Patient satisfaction with health care: the case of five multisectional hospitals. Journal of Medicine; 22(2): 16-27.

Ahmed, N.G. (2014). The effect of nursing management process applied by head nurses on quality of patient care in the main Mansoura University hospital. Master dissertation. Faculty of Nursing, Bani Swif University. 2, 35,51 .

Aly, S.H. (2011). Designing a system for quality improvement for the administrative structure of the nursing service department at Kasr El-Einy center of radiation oncology and nuclear medicine. Doctoral dissertation. Faculty of Nursing, Cairo University. 130 132.

American Physical Therapy Association. (2017). Patient care. Retrieved from: http://www.apta.org/patientcare

Basavanthappa, B.T. (2009). Nursing Administration. $2^{\text {nd }}$ ed. Jaypee Brothers Medical Press, New Delhi. 68-118, 505-538.

Cortelyou-Ward, K. (2009). Work environment and the effect on occupational commitment and intent to leave: a study of Bedside Registered Nurses. Retrieved from:

http://webcache.googleusercontent .com/search?q=cache:f4HTGhmh YUJ:citeseerx.ist.psu.edu/viewdoc 
Relationship between the Quality of Administrative System and Health Care Provided to the Patients among Hospital Managers

/download\%3Fdoi\%3D10.1.1.840. 4674\%26rep\%3Drep1\%26type\%3 Dpdf $+\& c d=1 \& h l=e n \& c t=c \operatorname{lnk} \& g l$ =eg

Elbialy, G. and Abd Elaal, N. (2013). Essentials of magnetism as perceived by staff nurses at Alexandria German hospital, Life Science Journal; 10(4): 23-27.

Gad R. (2002). Quality care as perceived by nurses, physicians and health care consumers. Unpublished master dissertation. Faculty of Nursing, Ain Shams University. 5,111-113.

Gharib, S.A. (2013). Job satisfaction of nursing staff, versus patients' satisfaction with the quality of nursing services at Cairo university hospitals. Master dissertation. Faculty of Nursing, Cairo University. 80-90.

Hospital Management System Project. (2014). Retrieved from: www.slideshare/himanicopra/hosp ital-management-system-project

Huber, D. (2018). Leadership and Nursing Care Management. $6^{\text {th }}$ ed. Elsevier Inc, china. 187, 286-88.

Hussein, H.M. (2014). Relationship between nurses and physicians' perceptions of organizational health and quality of patient care. Eastern Mediterranean Health Journal; 20(10): 634-636.

Ibrahim, E.E. (2016). Organizational features of work environment and nurses' quality of work life. Master dissertation. Faculty of Nursing, Menoufia University. 101-104.

Kelly, P. (2012). Managing Quality and Risk. Leading and Managing in Nursing. $3^{\text {rd }}$ ed. South-Western Cengage Learning Press. USA. 13-15.

Kevin, T. and Sullivan, A. (2018). Open Epi: sample size for X-sectional, Cohort and Clinical Trials.

\section{Retrieved}

from:http://www.openepi.com/Sa mpleSize/SSCohort.htm.

Marquis, B., and Huston, C. (2011). Leadership Roles and Management in Nursing: Theory and application. Lippincott co, New York.

Mohamed, R.A. (1998). The effect of using total quality management on the efficiency of the general authority for health insurance hospitals. Master dissertation. Faculty of Commerce, Tanta University).

Mohamed, S.A. (2002). Relationship between job satisfaction and absenteeism among nurses. Master dissertation. Ain Shams University. 110-120.

Mosadeghrad A.M. (2014). Factors influencing health care service quality. Journal of Health Policy and Management; 3(2): 77-89.

Parand A., Dopson S., renzl A. \& Vincent C. (2014). The role of hospital managers in quality and patient safety: a systematic review. Journal of Clinical Pathology BMJ. 4(9): 500-05.

Salah, S A. (2016). Quality of nursing care barriers in critical care units at Tanta university hospitals. Master dissertation. Faculty of Nursing, Tanta University. 6-10.

Siddiqui, M.I. (2016). Hospital Administration. $8^{\text {th }}$ ed. Time Publishers company. 235-46.

Williams, C. (2013). Principles of Management. South- Western Learning Press, USA. 4-27.

Williams D. (2015). Patient satisfaction survey. Factors influencing patient satisfaction in hospitals. Retrieved from: https://www.surveymonkey.com/r/ $\underline{\text { ZNCZ3RC }}$ 